\title{
WORKING paper \\ How do lenders price energy \\ efficiency? Evidence from personal consumption loans
}

\author{
Louis-Gaëtan Giraudet ${ }^{1}$, Anna Petronevich ${ }^{2}$ \\ and Laurent Faucheux ${ }^{3}$
}

March 2019, WP \#716

\begin{abstract}
At least ex ante, energy efficiency improvements increase investor's solvency. Associated loans should therefore carry lower interest rates than do otherwise conventional loans. We test this hypothesis using unique weekly panel data on posted interest rates scraped from loan simulators made available online by French credit institutions during 2015-2016. On average, we find that lenders charged a green premium in 2015 but offered a green discount in 2016. We also find that, absent green attributes, interest rates are higher for home retrofit loans than for vehicle loans, which suggests that lenders use the loan purpose as a screening device of unobserved borrower characteristics. Our results together imply that loans for home energy renovation were consistently charged relatively high interest rates, with adverse consequences for scaling up home energy renovation.
\end{abstract}

Keywords: energy efficiency gap, personal consumption credit loan, home energy retrofit, screening, data scraping, online prices

JEL classification: D14; G21; Q41

1 Ecole des Ponts ParisTech and Centre International de Recherche sur l'Environnement et le Développement (CIRED), giraudet@centre-cired.fr ;

${ }^{2}$ Financial economics research division, anna.petronevich@banque-france.fr ;

${ }^{3}$ CNRS and Centre International de Recherche sur l'Environnement et le Développement (CIRED), faucheux@,centre-cired.fr

We gratefully acknowledge funding from the European Investment Bank Institute under the University Research Sponsorship Programme, Grant EIBI/KnP/TT/ck (1-RGI-C311). We thank Dominique Berthon for excellent research assistance that set the stage for the project. We thank Leonardo Gambacorta, Sven Heim, Sébastien Houde, Elisabetta Iossa, Claire Labonne, Antoine Lallour, Maria Loumioti, Antoine Mandel, Tien Viet Nguyen, Julia Schmidt, Mattia Girotti and seminar participants at ETH Zürich and CERNA Mines ParisTech for useful comments on earlier drafts. All remaining errors are ours.

Working Papers reflect the opinions of the authors and do not necessarily express the views of the Banque de France. This document is available on publications.banque-france.fr/en 


\section{NON-TECHNICAL SUMMARY}

Energy efficiency is commonly viewed as the most cost-effective way to reduce carbon dioxide emissions. As many energy-efficiency measures involve high upfront costs, financing is key to scaling up investment. Effective deployment therefore requires that energyefficiency loans be priced efficiently. While "credit constraints" are frequently cited as a major barrier to energy efficiency, however, little is known about their nature and magnitude (Palmer et al., 2012).

In theory, a variety of information asymmetries might affect the supply of energy-efficiency loans. On the one hand, energy-efficiency measures, such as home energy retrofits (renovation), should reduce energy expenditures. Compared to an otherwise conventional investment, say the purchase of an automobile, such an "extra-return" should increase the borrower's creditworthiness, hence drive interest rates down. The effect however vanishes if the lender ignores predicted energy savings, which, according to several studies, might be overestimated (Fowlie et al., 2015). On the other hand, whereas $75 \%$ of car purchases in France are financed by loans, this share is as low as $20 \%$ for home retrofits, despite comparable amounts borrowed.4 This suggests that borrowers have heterogeneous preferences for different types of loans, which lenders can exploit to price discriminate. As a result, the net effect of energy-efficiency attribute juxtaposed on the loan type effect (extrabut imperfectly observable return, heterogeneous preferences) on the interest rates is ambiguous.

In this paper, we test whether the pricing of energy-efficiency loans differs from that of otherwise conventional investments. We use a panel dataset of posted interest rates collected on online credit simulators in France. An interesting feature of the collected data is that consumer information (e.g., age, income, risk profile) is not required in online simulations. We can therefore concentrate on project-based discrimination without being confounded by applicant-based discrimination. Focusing on unsecured consumer credit also allows us to abstract from issues involving collateral.

Our analysis reveals that loan terms for home energy retrofits, contrary to intuition, carry relatively high interest rates. The results suggest that, on average, home energy efficiency is subject to a double energy efficiency gap: the first because renovation projects carry relatively high interest rates with respect to vehicle projects, the second because within the renovation category, the green attribute further increases the interest rate.

Our data undergo important changes in the beginning of 2016, with the rates for green projects shifting significantly downside (which is plausibly related to Quantitative Easing of the European Central Bank), as can be seen in the Figure below. We find a green discount in 2016, but not in 2015. This result is consistent with the notion that financial agents increasingly value environmental aspects, as recently substantiated by An and Pivo (2018) in the US market for commercial mortgages and Karpf and Mandel (2018) in the US market for municipal bonds. Regarding the price discrimination, we observe it in both 2015 and 2016, however, to a larger extent in 2016. This leads us to the conclusion that the double energy efficiency gap observed over the period is not consistent: in 2015, only its first dimension applies, whereas in 2016, only its second dimension applies. In other words, the market seems to increasingly recognize the lower risk associated with green projects, but charges increasingly higher interest rates for renovation projects than for vehicles.

\footnotetext{
${ }^{4}$ Sources: http://www.ademe.fr/open-observatoire-permanent-lamelioration-energetique-logement-campagne-2015, http://www.latribune.fr/vos-finances/banques-credit/credit-auto-moto/20101007trib000556639/les-francaisrecourent-toujours-largement-au-credit-pour-acheter-leur-voiture.html, http://www.lefigaro.fr/conso/2015/05/04/05007-20150504ARTFIG00162-credit-conso-le-profil-type-de-lemprunteur-en-cinq-chiffres.php
} 
Figure: Average weekly posted interest rate by loan designation
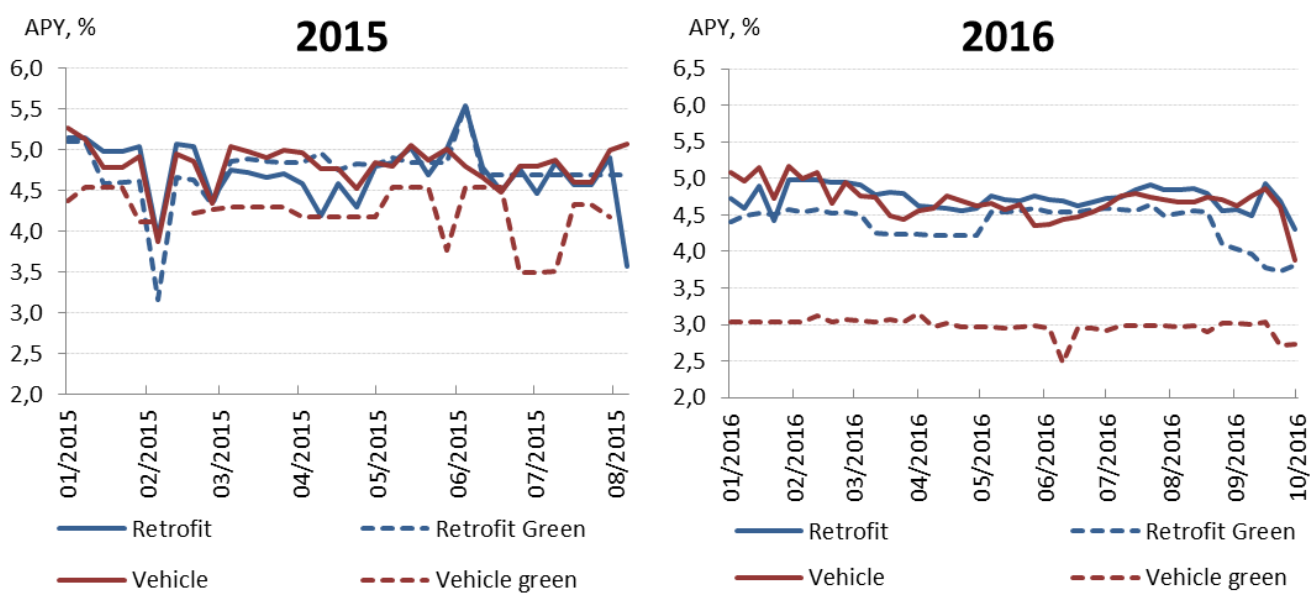

Note: APY stand for Average percentage yield, or the total interest rate (all charges included)

\section{Comment les prêteurs valorisent-ils les investissements d'efficacité énergétique? Le cas du marché français du crédit à la consommation}

\section{RÉSUMÉ}

A priori, l'amélioration de l'efficacité énergétique augmente la solvabilité des investisseurs. Les taux d'intérêt des prêts qui financent ces investissements doivent par conséquent être inférieurs à ceux des prêts classiques. Nous testons cette hypothèse en utilisant une base des donnée unique constituée de taux d'intérêts extraits chaque semaine de 2015 et 2016 des simulateurs de prêts mis en ligne par la plupart des organismes de crédit français. En moyenne, nous constatons que les prêteurs offraient des taux d'intérêt relativement plus élevés pour les investissements verts en 2015 et relativement plus bas en 2016. Nous observons également qu'en l'absence d'attributs écologiques, les taux d'intérêt sont plus élevés pour les crédits à la rénovation énergétique des logements que pour les crédits automobile. Ce dernier effet suggère que les prêteurs utilisent la destination du prêt comme un outil de screening des caractéristiques non observées des emprunteurs. Nos résultats impliquent que les crédits pour la rénovation énergétique des logements se voient attribuer des taux d’intérêt systématiquement élevés, ce qui constitue une barrière à l'objectif de massification des travaux de rénovation.

Mots-clés : efficacité énergétique, crédit à la consommation des particuliers, rénovation énergétique des logements, asymétrie d'information (screening), scraping des données, prix en ligne 


\section{Introduction}

Improving energy efficiency is recognized as the most cost-effective means of reducing carbon dioxide emissions at the source of anthropogenic global warming. This is particularly the case in the building and transportation sectors, which together contribute $30 \%$ of global emissions, two thirds of which come from households. The Intergovernmental Panel on Climate Change estimates that limiting global warming to $1.5^{\circ} \mathrm{C}$ above pre-industrial levels would require global investment in energy efficiency of $\$ 700$ billion in 2050, an upscale by a factor of 4 to 5 compared to 2015 (IPCC, 2018). The International Energy Agency suggests even higher numbers of $\$ 1.3$ trillion per year between 2026 and 2040 (IEA, 2018). As an attribute of long-lived assets, energy efficiency implies financing. In France alone, the average investment in home energy retrofit is $11,750 € ; 32 \%$ of retrofits involve credit, which typically covers over $50 \%$ of the upfront cost (ADEME, 2018). Meeting the 500,000 annual retrofit target set by the French Government thus creates annual borrowing needs of about one billion euros. Scaling up energy efficiency therefore requires that sizable borrowing needs be satisfied in an economically efficient manner. Despite its importance, however, the issue has received only little attention so far.

According to basic principles of finance, interest rates should reflect the risks associated with the underlying asset. As a first approximation, the risk associated with energy efficiency investments can be considered as low: by reducing energy expenditures, energy efficiency both increases the solvency of the investor and the resale value of the underlying asset - the latter phenomenon effect in particular is increasingly documented (e.g., Brounen and Kok, 2011; see Giraudet, 2018, for a review). A wellfunctioning credit market should therefore offer lower interest rates for energy efficient projects (hereafter "green projects") than for projects devoid of that attribute but otherwise similar (hereafter "conventional projects"). This simple prediction has recently been proved valid in the US market for commercial mortgages by An and Pivo (2018). Using ex post data from a loan programme, the authors find that those buildings that were certified green at loan origination obtained slightly but statistically significantly better loan terms than did their conventional counterparts. ${ }^{1}$ To our knowledge, this is the only study that has investigated the matter. Its internal validity is however threatened by selection issues, as the authors could not control for borrowers' characteristics.

In this paper, we assess the validity of what we refer to as the "green discount" hypothesis in the French market for personal consumption loans. To this end, we assembled a unique panel dataset of loan terms posted on credit institutions' websites. The data were retrieved every week, for two years, from loan simulators made available online by 15 institutions which cover the near totality of the French market. Our approach differs from that of An and Pivo (2018) in several respects. First, we consider a different market. While An and Pivo (2018) studied mortgage loans for new commercial buildings, we study unsecured loans for household investment; when it comes to buildings, we are concerned with the renovation of existing

\footnotetext{
${ }^{1}$ The authors additionally find that greener buildings entail lower default rates. They thus corroborate an earlier finding of Kaza et al. (2014) in the US market for residential mortgages. This robust result confirms one assumption of the "green discount" prediction, namely that green projects are less risky than conventional projects. According to An and Pivo (2018), however, the green attribute has a much smaller effect on loan terms than on default rates.
} 
ones rather than new constructions. ${ }^{2}$ Our broader focus allows us to examine whether the green attribute varies with the designation of the project. In that regard, assuming that the risk associated with a home retrofit and a vehicle purchase does not particularly differ, we expect the green discount associated with each designation, if any, to be the same online. Second, and perhaps most importantly, our data are immune from sorting bias, as the online simulators which they originate from do not query any information about the prospective borrower's characteristics. We therefore avoid the selection issues faced by An and Pivo (2018). Third, these facilitating features come at the cost of handling ex ante, rather than ex post, data. This implies in particular that we cannot study default rates. Still, the fact that our posted data overestimate actual data by a mere 0.3 percentage point on average and that the two follow parallel trends lends external validity to our analysis.

In order to fully capture the interaction between the green dimension of the asset and its designation, we investigate two hypotheses - whether green projects are offered lower interest rates than their conventional counterparts on the one hand, and whether renovation and vehicle projects are priced the same, regardless of any green attribute, on the other. We do so by estimating a parsimonious econometric model of interest rate margin that includes time and institution fixed effects and controls for loan characteristics. When considering the period as a whole, we fail to reject the first hypothesis and find higher interest rates for renovations than for retrofits, which leads us to reject the second hypothesis. Overall effects are small (except for green vehicles) but statistically significant and confirmed by statistical tests and robustness checks, including placebo tests. Looking at each year separately, we find that both results hold for 2016 but were reversed in 2015. In other words, the market seems to increasingly value the lower risk associated with green projects while increasingly offering higher interest rates for renovation projects than for vehicles. This has important consequences for green renovation projects, which, owing to the interaction between these two trends, constantly carry relatively high interest rates. This is especially true for short-term loans (12 months).

Our contribution is two-fold and strictly positive. One speaks to the energy efficiency field. By documenting relatively high interest rates for home energy retrofits, we contribute to the literature on the factors causing under-investment in energy-efficient technologies - a phenomenon known as the energyefficiency gap (Jaffe and Stavins, 1994). While most research into the issue has focused on behavioural factors on the demand side (Gillingham et al., 2009; Allcott and Greenstone, 2012; Gerarden et al., 2017), we focus on less-studied supply-side factors. Specifically, we add to the scarce literature on energy efficiency loans (Palmer et al., 2012; Kaza et al., 2014; An and Pivo, 2018) by emphasizing the interaction between the green attribute and other dimensions of the underlying asset. Given the high sensitivity of loan demand to loan terms (as estimated in credit cards by Gross and Souleles, 2002, and Ponce et al., 2014), removing premia on interest rates could significantly increase investment in home energy retrofit. Our second contribution is more general and relates to the literature on unsecured credit market (Artheya et al., 2012, Sánchez, 2018, Crawford et al., 2018). We document an anomaly, namely systematic differences in the interest rates offered for renovation- and vehicle-backed loans, whereas the risks

\footnotetext{
${ }^{2}$ Given the slow turnover of building stocks (typically $1 \%$ every year), the renovation of existing buildings is much more crucial for carbon dioxide emission reductions than are new constructions. This is especially true in the residential building stock, which is typically $50 \%$ larger than the commercial building stock.
} 
associated with each project should not particularly differ. Considering that our data are immune from sorting bias, we interpret this finding as lenders using loan designations as a screening device of unobserved borrower characteristics in a way conducive to rationing. Our finding echoes Einav et al. (2012)'s one that down payments can also be used as screening device. Altogether, these findings contribute to the scarce literature on price discrimination by lenders facing ex ante hidden information on borrower characteristics (Zinman, 2014; Allen et al., 2014a,b).

The analysis proceeds as follows. Section 2 formulates testable hypotheses. Section 3 describes the data. Section 4 details the empirical approach. Section 5 discusses the results. Section 6 provides robustness checks. Section 7 discusses welfare implications and concludes.

\section{Testable hypotheses}

Here we discuss in greater length the hypotheses that our dataset allows us to test. As stated in the introduction, basic principles of finance imply the following:

Hypothesis 1: Green projects carry lower interest rates than do conventional projects.

Rejection of this hypothesis can be interpreted as evidence of an energy efficiency gap. An increasing number of studies point to energy retrofit projects that fail to deliver predicted energy savings (Metcalf and Hassett, 1999; Graff Zivin and Novan, 2016; Fowlie et al., 2018). While these studies attribute the missing savings to modeling flaws in engineering calculations, Giraudet et al. (2018) propose an alternative explanation rooted in information asymmetries. Evaluating a home weatherization program conducted in Florida, the authors provide evidence that retrofit contractors engage in moral hazard by under-providing quality in hard-to-observe measures such as insulation installation or duct sealing. Thus confronted with a so-called lemons problem (Akerlof, 1970), the lender might internalize it and price energy-efficient assets the same as conventional, non-energy-efficient assets.

Hypothesis 1 could also be rejected if green projects are subsidized and lenders take advantage of some market power to extract the borrower's surplus from the subsidy. In fact, both home energy retrofits and the purchase of green vehicles are covered by a variety of subsidy programs - income tax credits, zerointerest rate loans and reduced value-added tax for the former (Giraudet et al., 2018b), feebates for the latter (d'Haultfoeuille et al., 2014). Importantly, these programs did not undergo substantial changes over the 2015-2016 period. So if surplus extraction interpretation is valid, we expect the green effect to go in this same direction for both renovations and vehicles.

Now, regardless of any energy efficiency consideration, a renovation and a vehicle are two household investments which, as a first approximation, carry comparable risk. In a well-functioning credit market, the following hypothesis should therefore hold:

Hypothesis 2: The interest rates for renovation and vehicle projects are identical. 
This hypothesis may however be rejected if the lender uses the loan designation as a screening device of unobserved borrower characteristics. ${ }^{3}$ In this perspective, a plausible conjecture formed by the lender is that households borrowing money to retrofit their home are wealthier than those borrowing money to purchase a vehicle. Indeed, vehicle purchases are largely disconnected from borrowers' home ownership status, while home energy retrofits are overwhelmingly conducted by homeowners (79\% in France, according to ADEME, 2018), who tend to be wealthier. ${ }^{4}$ Such a conjecture can have two countervailing effects. On the one hand, a wealthier borrower can be perceived as having a higher willingness to pay, which a price-discriminating lender may want to exploit by charging higher interest rates. This effect, which we refer to as the "WTP channel," is common to the supply of any good. On the other hand, a wealthier borrower might be perceived as less likely to default, hence be charged a lower interest rate. This effect, which we refer to as the "risk channel," is specific to loans. This leads us to consider an amended version of Hypothesis 2:

Hypothesis 2': Renovation projects carry lower interest rates than do vehicle projects.

Rejection of Hypothesis 2' can be interpreted as dominance of the WTP channel over the risk channel, while failure to reject it conveys the opposite. From a welfare perspective, the WTP channel has more detrimental consequences, since it may drive some borrowers out of the market.

\section{Data}

\subsection{Collection}

Our dataset consists of a panel of interest rates retrieved from online credit simulators. Most credit institutions in France make such simulators available to prospective borrowers. A simulator typically makes queries about the amount, duration and designation of the desired loan, from which it returns loan terms, characterized by the fixed nominal interest rate, possibly some fees, and the annual percentage yield (taux annuel effectif global), which expresses the yearly cost of the loan. Importantly, simulators do not make queries about the applicant's characteristics. The resulting loan-term data are therefore plausibly immune from sorting bias based on applicants' characteristics observed to the lender.

We designed a web-scraping robot that ran such simulators on a weekly basis and assembled a panel dataset of simulated loan terms. We surveyed all credit institutions which, to our knowledge, offered online simulators for household unsecured credit in France during the observation period. This includes 15 institutions which are either the main retailer or some credit subsidiaries of the six main French banking groups, altogether covering $88 \%$ of issued household loans (Table 1 ). We operated the robot for two years,

\footnotetext{
${ }^{3}$ In practice, loans terms are negotiated between the lender and the borrower during the underwriting process, at which time the lender does observe many of the applicant's characteristics. Screening probably becomes irrelevant at that stage. It is more likely to occur earlier on when loan terms are posted, then generating differences in interest rates that subsequent negotiation might not completely clear. This early process is the one studied here.

${ }^{4}$ Anecdotal evidence moreover suggests that borrowers are on average seven years older in retrofit loans than in auto loans (Meilleurstaux.com, 2015)
} 
from January 2015 to October 2016, which produced 93 weeks of data. Each week, for a given institution offering a given designation, the robot ran the simulator 108 times, combining 12 different amounts ranging from $5,000 €$ to $32,500 €$, with a step of 2,500€ - and 9 different maturities - ranging from 12 to 108 months, with a step of 12 . The data thus produced are 4-tuples of institution, designation, amount and maturity.

Table 1: Characteristics of the institutions surveyed

\begin{tabular}{lcll} 
Banking Group & Market share & \multicolumn{1}{c}{ Institution } & Type of institution \\
\hline BNP Paribas & $11 \%$ & BNP Paribas & Private bank \\
& & Cetelem & Financial credit establishments \\
& & Cofinoga & Financial credit establishments \\
BPCE & $8 \%$ & Comofinance & Financial credit establishments \\
Crédit Agricole & $10 \%$ & Crédit agricole & Cooperative bank \\
& & LCL & Cooperative bank \\
& & Sofinco & Private bank \\
Crédit Mutuel & $48 \%$ & Cofidis & Financial credit establishments \\
& & Crédit Mutuel & Financial credit establishments \\
& & Financo & Cooperative bank \\
& & Prêt d'union & Financial credit establishments \\
\hline La Banque Postale & $6 \%$ & La Banque Postale & Financial credit establishments \\
\hline
\end{tabular}

Note: Market share estimates were computed by the authors using data from the Banque de France (CEFIT database). The institutions surveyed cover $88 \%$ of the market

Several sampling issues made our panel dataset unbalanced. First, the menus of designations are specific to each institution, and the number of options each offers varies from 1 to 21 (median 4; mean 7.5). Overall, we recorded 90 different designations, which we grouped into categories, as we will see in the next section. Second, the available ranges of amount and maturity vary as well across institutions. Yet even though sampling was heterogeneous across institutions, this did not introduce a strong bias, as amounts and maturities are very close once averaged per loan category (Figure 1). The average loan size and maturity over the whole dataset are $16,782 €$ and 47 months, respectively. ${ }^{5}$ Third, some data could not be retrieved for certain institutions on certain weeks. This is due to changes in websites that could not be detected early enough to adjust the design of the robot - a challenge common in web scraping (Cavallo and Rigobon, 2016). Overall, our workable panel dataset comprises 240,962 observations.

\footnotetext{
${ }^{5}$ To put these numbers in perspective, the typical figures are $11,449 €$ and 47 months, respectively (Meilleurtaux.com, 2015).
} 

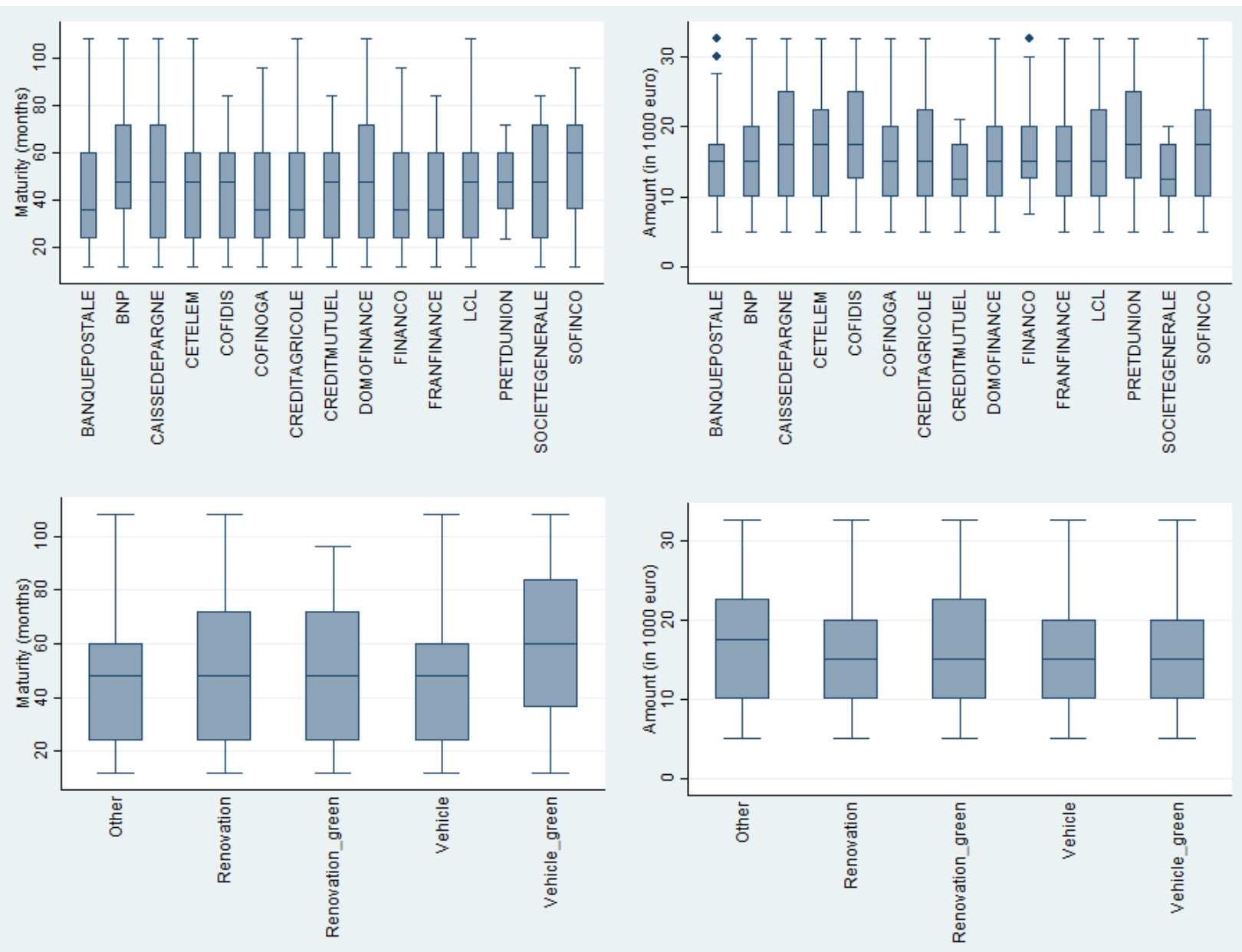

Figure 1: Summary statistics of simulated amounts and maturities

\subsection{Loan categorization}

The number and labelling of options offered by institutions in their menu of loan designations vary widely. After grouping redundant labels, we still handle 90 distinct designations, which are all variants of vehicle loans, home renovation loans, equipment loans, consumption loans, student loans, health loans and cash loans. These designations are representative of unsecured loans issued in France, $47 \%$ of which were dedicated to auto purchase in $2017,19 \%$ to equipment purchase, $10 \%$ to home retrofits, $8 \%$ to consumption, $8 \%$ to liquidity, $4 \%$ to credit restructuring and $4 \%$ to tax payments (Mouillard, 2018).

To test the hypotheses stated in Section 2, we group the collected designations into broad categories. Combining the two hypotheses, we are specifically interested in four categories: renovations, green renovations, conventional projects, and green projects. Given the large market share of vehicle projects, we sort this category out of conventional investments. Another motivation for doing so is that one institution makes a distinction between green and conventional vehicles. Our most granular categorization therefore has five items: renovations, green renovations, vehicles, green vehicles, and others. To test the two hypotheses separately, we also consider two more aggregate categorizations: one that groups all green categories on the one hand, all conventional categories on the other; another that groups all 
renovation categories on the one hand, all vehicle categories on the other. The three workable categorizations are detailed in Table 2. Overall, eleven institutions offer both vehicle and renovation loans; four institutions - Cetelem, Domofinance, Financo and Prêt d'Union - offer both green and conventional retrofits; and one - BNP Paribas - offers both green and conventional vehicles.

Table 2: Categorization of loan designations

\begin{tabular}{|c|c|c|c|}
\hline Collected entries (90) & $\begin{array}{l}\text { 2-item } \\
\text { categorization }\end{array}$ & $\begin{array}{l}\text { 3-item } \\
\text { categorization }\end{array}$ & $\begin{array}{l}\text { 5-item } \\
\text { categorization }\end{array}$ \\
\hline Car, motorcycle & Conventional & Auto & Auto \\
\hline $\begin{array}{l}\text { Used car, used vehicle, used boat, used camping } \\
\text { car, used trailer, used motorcycle }\end{array}$ & Conventional & Auto & Auto \\
\hline $\begin{array}{l}\text { Brand new vehicle, Brand new car, Brand new or } \\
\text { less than } 2 \text {-year-old car, brand new or less than } 2 \text { - } \\
\text { year-old camping car, brand new or less than } 2 \text { - } \\
\text { year-old trailer, brand new or less than } 2 \text {-year-old } \\
\text { motorcycle }\end{array}$ & Conventional & Auto & Auto \\
\hline Brand new efficient car & Green & Auto & Auto green \\
\hline $\begin{array}{l}\text { Other works, decoration, construction, veranda, } \\
\text { indoor/outdoor design }\end{array}$ & Conventional & Renovation & Renovation \\
\hline $\begin{array}{l}\text { Boiler, wood boiler, electrical heating, water } \\
\text { heating, windows, insulation, heat pumps, heating, } \\
\text { home improvement }\end{array}$ & Green & Renovation & $\begin{array}{l}\text { Renovation } \\
\text { green }\end{array}$ \\
\hline $\begin{array}{l}\text { Other project, consumption, relocation, wedding, } \\
\text { birth, DIY supplies, holidays, event, leisure }\end{array}$ & Conventional & Other & Other \\
\hline Health, Family problems & Conventional & Other & Other \\
\hline Need for money, Need for cash, budget & Conventional & Other & Other \\
\hline Student loan & Conventional & Other & Other \\
\hline $\begin{array}{l}\text { Electronic device, appliances, Hi-fi, furniture, } \\
\text { computer accessories }\end{array}$ & Conventional & Other & Other \\
\hline
\end{tabular}

The categorization procedure is crucial. Most collected designation labels are unambiguous and their allocation to the appropriate category is straightforward. This is not quite the case for green and conventional retrofits, which are nevertheless central to our analysis. Making a distinction between the two requires careful interpretation of the labels. Our chosen approach is to allocate to the green retrofit category those retrofit labels that likely reduce the energy consumption of a household. This essentially includes measures on the building envelope and the space and water heating systems. As a robustness check, we subject this categorization to placebo tests and conclude that it is meaningful (see Section 6.2).

\subsection{Descriptive statistics}

We focus below on the average percentage yield (APY), which represents the monthly price of a loan, including the fees. An obvious concern with our posted data is the accuracy with which they approximate actual data. Comparing the trend of the average interest rate in our dataset, weighted by the market share 
of the corresponding banking group, to that of issued loans as provided by the Banque de France, ${ }^{6}$ we find a positive spread on 73 weeks out of 93 (Figure 2). The mean percentage error over the whole period is $6.0 \%$ (mean absolute percentage error: $6.9 \%$; standard error $4.7 \%$ ), or a 0.3 percentage point. Such a relatively low error lends external validity to our data. Moreover, the fact that the rates on issued loans are almost systematically below posted rates can be interpreted as indirect evidence of the negotiation process lenders and borrowers are known to engage in (see Allen et al., 2014a,b, for evidence from Canada).

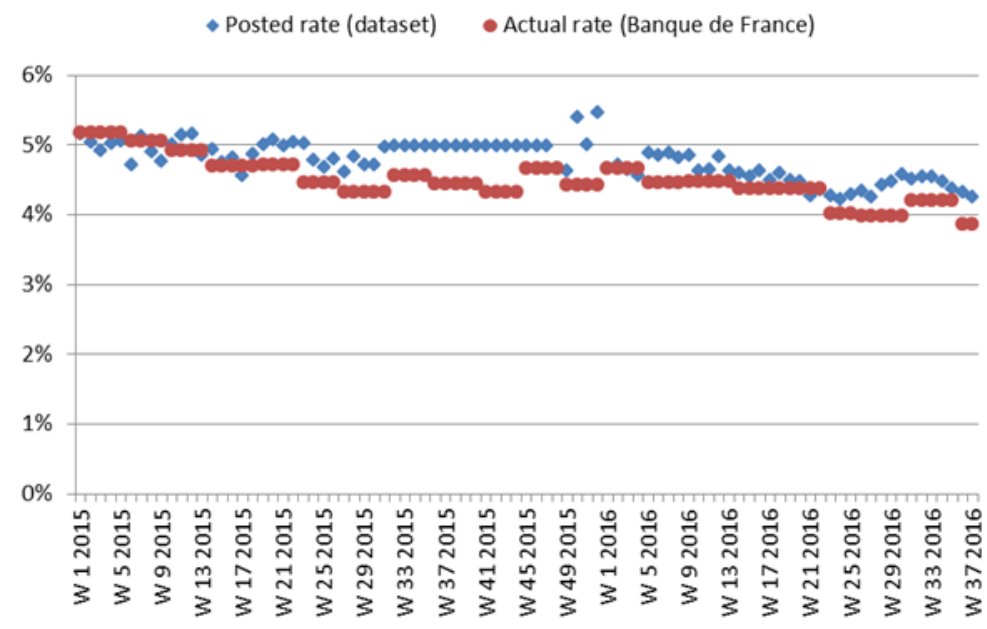

Figure 2: Comparison between posted and actual interest rates

The interest rates posted by credit institutions exhibit some dispersion across space and time. On average, the surveyed institutions update their interest rates every seven weeks and exhibit a coefficient of variation on interest rate of $33 \%$ (Figure 3 , red square). As we will see later in regressions, dispersion is further substantiated by strong variations in average interest rates across banks. This indicates that despite operating in a highly competitive market (Europe Economics, 2009), institutions adopt heterogeneous pricing strategies, probably driven by differences in their borrower portfolio.

\footnotetext{
${ }^{6}$ http://webstat.banquefrance.fr/fr/browseChart.do?node=5385583\&sortByView454=468\&SERIES_KEY=MIR1.M.FR.B.A2B.A.R.A.2254U6.E UR.N\&SERIES_KEY=MIR1.M.FR.B.A2B.A.R.A.2250U6.EUR.N
} 


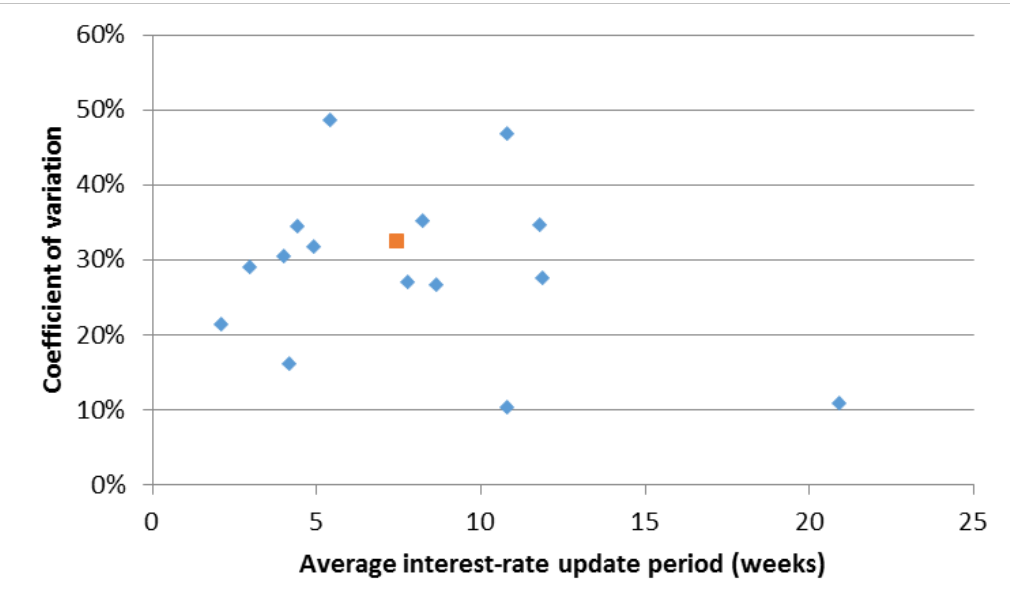

Figure 3: Dispersion of average interest rates across space and time, by institution

A glimpse into the time series of weighted averages of interest rate suggests that some clear, yet unstable, differences exist between categories (Figure 4). The two green categories tend to be associated with lower interest rates. In particular, the average interest rate on green vehicles - which we recall are offered by BNP Paribas only - drops significantly early in 2016.

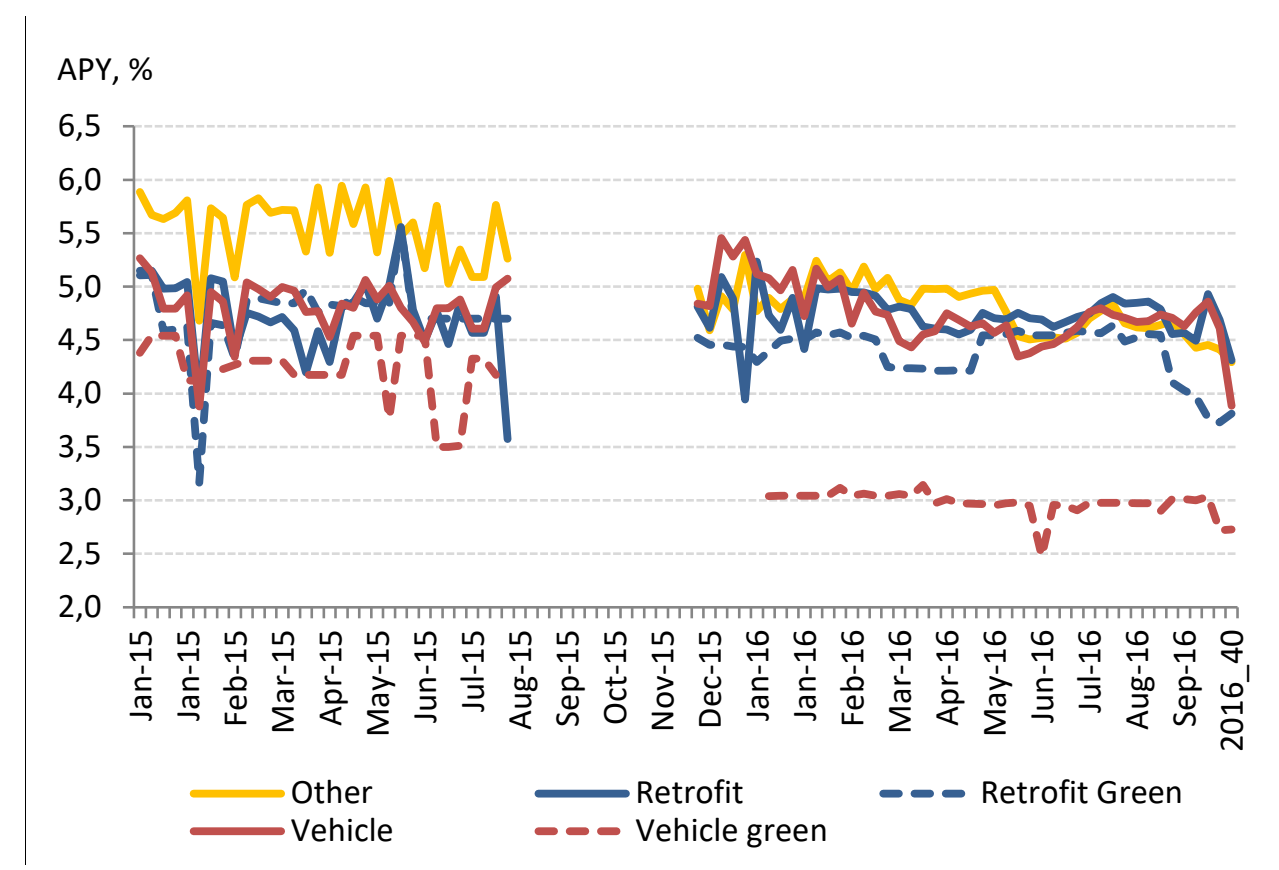

Figure 4: Time series of average spread (in percentage points), by category

Another glimpse suggests that the interest rates averaged by maturity co-move to a large extent (Figure 5). Yet 12-month loans exhibit a peculiar pattern, with an interest rate decreasing more markedly than that of other maturities from early 2016 onwards. This coincides with an increase in deposits of 154 billion euros between 2015 and 2016 induced by quantitative easing by the European Central Bank (ACPR, 2016). 
It is likely that banks offered particularly low interest rates on short-term loans to recycle these vast amounts of cash money.

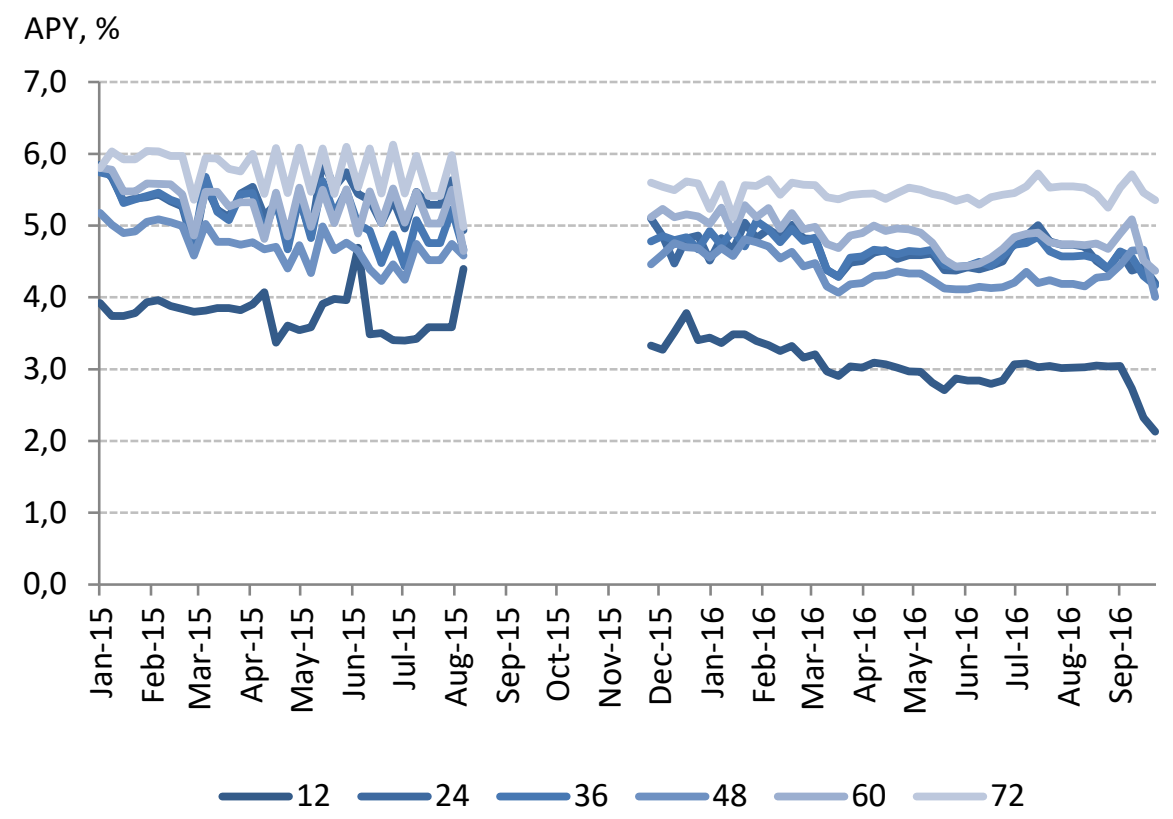

Figure 5: Time series of average spread (in percentage point), by maturity

Figure 6 sheds light on the interaction between these phenomena through the market yield curve, which illustrates how interest rates vary with maturities. We constructed the yield curves for each category using the Nelson-Siegel-Svensson model (Nelson and Siegel, 1987) and estimated them at one point in 2015 and a year after.
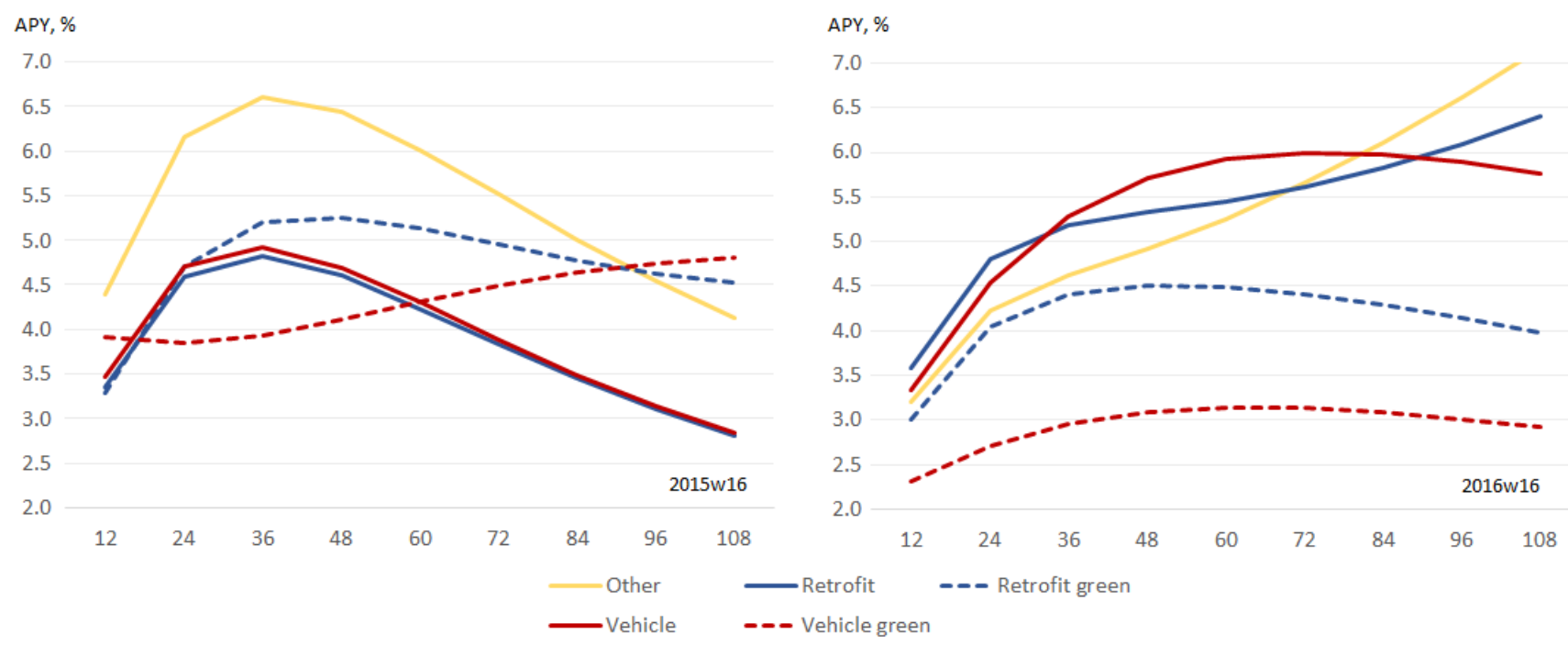

Figure 6: Empirical yield curves at two points in time, by category 
We observe that all categories (except green vehicles) exhibited a bell-shaped curve in 2015, with a negative slope for high maturities. In 2016, expectations went back to normal, with a more usual positive slope for conventional categories. The two green categories however underwent a downward shift, which suggests recognition of the lower risk associated with green projects.

These observations call for a separate analysis of interest rates across maturities (12-month versus higher maturities) and over time (2015 versus 2016).

\section{Econometric model}

Our goal is to make inference on how credit institutions perceive the risks associated with different loan designations. We consider the spread $s$ between the posted interest rate $i$ (measured as the APY) in our dataset and the spot yield of the government bond $b$ of the same maturity: ${ }^{7}$

$$
s_{\text {kamtc }}=i_{\text {kamtc }}-b_{m t}
$$

where $k \in\{1, \ldots, 15\}$ denotes the credit institution, $a \in\{5000,7500, \ldots, 32500\}$ the amount simulated in euros, $m \in\{12,24, \ldots, 108\}$ the maturity of the loan in months, $c$ one category within one of the three retained categorization and $t$ the week on which the loan was simulated. Regressing the spread instead of using government bonds to explain the interest rate allows us to address potential endogeneity problems between the two. It moreover allows us to focus on the bank margin, which is the part of the interest rate most affected by loan designations. Note that, as government bonds carried negative yields over the period, the spread is generally larger than the associated interest rate.

We consider a parsimonious model that expresses the spread as a linear combination of the following determinants:

$$
s_{\text {kamct }}=\alpha_{0}+\alpha_{1} L_{a m}+\alpha_{2} I_{k}+\alpha_{3} T_{t} I_{k}+\beta_{c} D_{c}+\varepsilon_{k a m c t},
$$

where $L_{a m}$ is a vector of loan characteristics, including the duration of the loan, its square, and the amount borrowed, $I_{k}$ is a vector of institution fixed effects, $T_{t}$ a vector of time fixed effects and $D_{c}$ a vector of project categories. Through the institution fixed effect, we assume that different lenders adopt different pricing strategies, depending on their client portfolio, size or capitalization. The product $T_{t} I_{k}$ captures institutions' individual responses to changes in the macroeconomic and financial environment and helps address autocorrelation in the residuals. ${ }^{8}$ The associated coefficient $\alpha_{3}$ can be interpreted as the

\footnotetext{
${ }^{7}$ For the French government bond yields, we use the data on the observed yields for tradable maturities and inferred rates for nontradable maturities, as given by the ECB (Source: ECB, Data Source in SDW: Government bond, nominal, all issuers whose rating is triple A - Svensson model - continuous compounding - yield error minimization - Yield curve spot rate - Euro, provided by ECB).

${ }^{8}$ Classical heteroscedasticity tests do not apply to regressions with weighted observations. Nevertheless, visual inspection of residuals suggests little heteroscedasticity or autocorrelation.
} 
additional effect of a particular institution for a particular loan category with respect to the average effect of that institution $\alpha_{2}$ and the average effect of that loan category $\beta_{c}{ }^{9}$

The coefficients $\beta_{c}$ associated with loan categories are our main estimates of interest. We subject them to $t$-tests in order to assess the hypotheses stated in Section 2, which we statistically reformulate as follows:

$$
\begin{aligned}
& \mathbf{H}_{\mathrm{a}}: \beta_{1}^{\text {green }}<\beta_{1}^{\text {conventional }} \\
& \mathbf{H}_{\mathbf{b}}: \beta_{1}^{\text {retrofit }} \leq \beta_{1}^{\text {vehicle }}
\end{aligned}
$$

We test $\mathrm{H}_{\mathrm{a}}$ with the two-item categorization, $\mathrm{H}_{\mathrm{b}}$ with the three-item categorization and examine the interaction of the two hypotheses with the five-item categorization. To ensure representativeness of our loan sample, we assign weights to our observations proportional to the share of the corresponding banking group in the French market for personal consumer credit (Table 1). We further assign uniform weights to all subsidiaries within a banking group.

\section{Estimation results}

\subsection{General effect of loan designation}

We estimate three variants of the model with ordinary least squares (OLS): model 1 uses the two-item categorization; model 2 uses the three-item categorization; model 3 uses the five-item categorization (Table 3). As expected, the spread is positively related to the duration, though at a slightly decreasing rate. An additional year increases the spread by about 0.4 percentage point. In contrast, the amount has a very small, negative effect on the spread.

Table 3: OLS estimates of the baseline regression

\begin{tabular}{lccc} 
Dependent variable: & Model 1 & Model 2 & Model 3 \\
\cline { 2 - 4 } spread APY (in percentage points) & 2 categories & 3 categories & 5 categories \\
\hline \multirow{2}{*}{ Constant (Other) } & $4.50^{* * *}$ & $4.51^{* * *}$ & $4.51^{* * *}$ \\
& $(-39.66)$ & $(-39.6)$ & $(-39.58)$ \\
Duration (month) & $0.03^{* * *}$ & $0.03^{* * *}$ & $0.03^{* * *}$ \\
& $(-41.17)$ & $(-41.13)$ & $(-41.01)$ \\
Duration^2 & $-0.00^{* * *}$ & $-0.00^{* * *}$ & $-0.00^{* * *}$
\end{tabular}

\footnotetext{
${ }^{9}$ The institution and institution*time fixed effects allow us to deal with the cross-institution correlation and the autocorrelation of the error terms. This increases the precision of our estimates. One would also like to cluster errors by designation or institution to account for intra-institution correlation. Yet that would be equivalent to assuming no correlation between the clusters, which, given the high degree of competition in the banking market, we consider a restrictive hypothesis. Moreover, a robust estimation would require many more clusters - typically 40 to 50 (Angrist and Pischke, 2009).
} 


\begin{tabular}{lccc} 
& $(-20.92)$ & $(-21.01)$ & $(-20.86)$ \\
Amount $(10,000 €)$ & $-0.02^{* * *}$ & $-0.02^{* * *}$ & $-0.02^{* * *}$ \\
& $(-45.83)$ & $(-45.81)$ & $(-45.76)$ \\
Green dummy & $-0.02^{* *}$ & & \\
Renovation & $(-2.97)$ & & \\
Vehicle & & $0.03^{* *}$ & $0.02^{*}$ \\
& & $(-2.66)$ & $(-2.07)$ \\
Renovation green & & $-0.04^{* * *}$ & $-0.03^{*}$ \\
& & $(-3.35)$ & $(-2.55)$ \\
Vehicle green & & & $0.04^{* * *}$ \\
& & & $(-3.76)$ \\
& & & $-0.50^{* * *}$ \\
Institution dummy & & & $(-33.56)$ \\
Institution dummy*Time dummy & & & \\
& YES & YES & YES \\
\hline $\mathrm{N}$ & YES & YES & YES \\
R-sq & & & \\
adj. R-sq & 240,962 & 240,962 & 240,962 \\
\hline
\end{tabular}

t-statistics in parentheses

$* p<0.05, * * p<0.01, * * * p<0.001$

The comparison of projects dummies across models suggests that green projects are priced below conventional projects (model 1 ) and that vehicle projects are priced below renovation projects (model 2 ). These results are statistically significant at conventional levels and confirmed by $t$-tests (Table 4), but small in magnitude. Interacting the two dimensions in model 3, we see that the former result does not apply to renovations and is in fact driven by the strong discount observed on green vehicles, which we recall is attributable to one institution. Again, these results are statistically significant and confirmed by $t$-tests.

The observed differences in marginal prices for vehicles and home renovation suggest that discrimination is at play: faced with ex ante hidden information about borrower characteristics, lenders use the loan purpose as a screening device. The polarity we obtain suggests that the WTP channel prevails over the risk channel. Our result thereby adds to the scare literature seeking evidence of information asymmetries in consumer credit (Zinman, 2014). It is in particular close to the finding of Allen et al. (2014a,b) that lenders price mortgages in a way consistent with discrimination based on unobserved bargaining power of borrowers.

Table 4: Statistical tests on the baseline regression

\begin{tabular}{lcccc} 
& & Model 1 & Model 2 & Model 3 \\
\cline { 3 - 4 } Hypotheses tests & Hypothesis & 2 & 3 & 5 \\
& & categories & categories & categories \\
\hline
\end{tabular}


HO: $\beta$ _green $=0$

$\mathrm{H} 1: \beta$ _green $\neq 0$

$\mathrm{t}$-stat value

p-value

Reject HO?

HO: $\beta$ _renovation $<\beta \_$vehicle

$\mathrm{H} 1$ : $\beta$ _renovation $>\beta \_$vehicle

$\mathrm{t}$-stat value

p-value

Reject HO?

HO: $\beta$ renovation_gr $<\beta$ renovation

$H 1$ : $\beta$ renovation_gr $>\beta$ renovation

t-stat value

p-value

Reject HO?

HO: $\beta$ _vehicle_gr $<\beta$ _vehicle

$H 1: \beta$ _vehicle_gr $>\beta$ _vehicle

t-stat value

p-value

Reject $\mathrm{HO}$ ?
$\mathrm{Ha}_{\mathrm{a}}$

0.00

yes

$\mathrm{H}_{\mathrm{a}}$

8.05

0.00

yes

$\mathrm{Ha}_{\mathrm{a}}$

2.66

0.00

yes

$\mathrm{Ha}_{\mathrm{a}}$

$-35$

0.00

no

Moreover, our results suggest that home energy efficiency is subject to a double energy efficiency gap: the first because renovation projects carry relatively high interest rates, the second because within this category, the green attribute further increases the interest rate. The fact that the green effect goes in opposite directions for vehicles and renovations allows us to rule out the surplus extraction explanation mentioned in Section 2.

\subsection{Effects by year of sample}

Motivated by the changes observed in the time series by categories (Figure 4) and changes in the yield curve (Figure 6), we estimate the different models on year subsamples (Table 5). The coefficients associated with duration indicate a steeper yield curve in 2016. The green discount observed over the period is only effective in 2016; conversely, in 2015, green projects carry a higher interest rate (model 1). Likewise, the ranking observed over the period between renovation and vehicle projects only applies to 2016 and is reversed in 2015 (model 2). The change in the merit order of the five categories observed in 2016 is consistent with an interaction between these two shifts (model 3). Again, all results are statistically significant and confirmed by $t$-tests. This leads us to the conclusion that the double energy efficiency gap observed over the period is not consistent: in 2015, only its first dimension applies, whereas in 2016, only its second dimension applies. In other words, the market seems to increasingly recognize the lower risk 
associated with green projects, but charges increasingly higher interest rates for renovation projects than for vehicles.

Table 5: Evolution of the effects

\begin{tabular}{|c|c|c|c|c|c|c|}
\hline \multirow{2}{*}{$\begin{array}{l}\text { Dependent variable: } \\
\text { Spread (in percentage points) }\end{array}$} & \multicolumn{2}{|c|}{ Model 1: 2 categories } & \multicolumn{2}{|c|}{ Model 2: 3 categories } & \multicolumn{2}{|c|}{ Model 3: 5 categories } \\
\hline & 2015 & 2016 & 2015 & 2016 & 2015 & 2016 \\
\hline \multirow[t]{2}{*}{ Constant (Other) } & $4.86 * * *$ & $5.88 * * *$ & $5.13^{* * *}$ & $5.80 * * *$ & $5.13 * * *$ & $5.79 * * *$ \\
\hline & $(44.70)$ & (28.59) & $(46.35)$ & $(27.67)$ & $(46.29)$ & $(27.6)$ \\
\hline \multirow[t]{2}{*}{ Duration (month) } & $0.028 * * *$ & $0.04^{* * *}$ & $0.02^{* * *}$ & $0.04^{* * *}$ & $0.03^{* * *}$ & $0.04^{* * *}$ \\
\hline & $(20.34)$ & $(43.16)$ & (19.49) & $(43.77)$ & (19.59) & (43.49) \\
\hline \multirow[t]{2}{*}{ Duration^2 } & $-0.00 * * *$ & $-0.00 * * *$ & $-0.00 * * *$ & $-0.00 * * *$ & $-0.00 * * *$ & $-0.00 * * *$ \\
\hline & $(-16.60)$ & $(-21.98)$ & $(-15.43)$ & $(-22.93)$ & $(-15.51)$ & $(-22.62)$ \\
\hline \multirow[t]{2}{*}{ Amount $(10,000 €)$} & $-0.02 * * *$ & $-0.02 * * *$ & $-0.02 * * *$ & $-0.02 * * *$ & $-0.02 * * *$ & $-0.02 * * *$ \\
\hline & $(-16.32)$ & $(-42.85)$ & $(-16.19)$ & $(-42.94)$ & $(-16.19)$ & $(-42.86)$ \\
\hline \multirow[t]{2}{*}{ Green dummy } & $0.06^{* * *}$ & $-0.06 * * *$ & & & & \\
\hline & $(8.78)$ & $(-8.55)$ & & & & \\
\hline \multirow[t]{2}{*}{ Renovation } & & & $-0.45 * * *$ & $0.19 * * *$ & $-0.47 * * *$ & $0.20 * * *$ \\
\hline & & & $(-21.12)$ & $(15.95)$ & $(-21.82)$ & (16.08) \\
\hline \multirow[t]{2}{*}{ Vehicle } & & & $-0.30 * * *$ & $0.03^{*}$ & $-0.29 * * *$ & $0.05^{* * *}$ \\
\hline & & & $(-13.65)$ & $(2.45)$ & $(-13.32)$ & (3.54) \\
\hline \multirow[t]{2}{*}{ Renovation green } & & & & & $-0.32 * * *$ & $0.13^{* * *}$ \\
\hline & & & & & $(-15.20)$ & (11.14) \\
\hline \multirow[t]{2}{*}{ Vehicle green } & & & & & $-0.27 * * *$ & $-0.78 * * *$ \\
\hline & & & & & $(-12.10)$ & $(-43.88)$ \\
\hline Institution dummy & YES & YES & YES & YES & YES & YES \\
\hline Institution dummy*Time dummy & YES & YES & YES & YES & YES & YES \\
\hline$N$ & 69,695 & 171,267 & 69,695 & 171,267 & 69,695 & 171,267 \\
\hline R-sq & 0.481 & 0.403 & 0.488 & 0.404 & 0.489 & 0.406 \\
\hline adj. R-sq & 0.476 & 0.401 & 0.484 & 0.402 & 0.485 & 0.404 \\
\hline
\end{tabular}

$\mathrm{t}$ statistics in parentheses

${ }^{*} p<0.05,{ }^{* *} p<0.01, * * * p<0.001$

A table similar to Table 4 could be presented for these results (as well as for the rest reported in this paper). To save space, we omit it here. However, since the standard errors of the estimates are very small, the differences between the estimated coefficients are always statistically significant, so the validity of the hypotheses can be verified simply by comparing the values of the corresponding coefficients.

Regarding the prevalence of WTP effect versus risk effect, higher rates for vehicles in 2015 advocate for the dominance of the risk effect; however, the relation flips over in 2016, with vehicle loans becoming relatively more affordable.

\subsection{Effects by loan maturity}

Motivated by the changes observed in the time series by maturities (Figure 5), we estimate model 3 on duration subsamples, considering separately 12 -month loans and loans with longer duration (Table 6). The ranking of categories for 12-month loans conforms that observed at the aggregate level. When considering loans with longer duration, this ranking changes in one important respect: green renovations are charged 
low interest rates only seconded by green vehicles. In other words, lenders seem to perceive green retrofits as riskier investments when financed by a short-term loan than when financed by a long-term loan. Further regressions on both year and maturity subsamples suggest that this phenomenon essentially occurred in 2016.

Table 6: Comparison of short-term and long-term effects

\begin{tabular}{|c|c|c|c|}
\hline \multirow{2}{*}{$\begin{array}{l}\text { Dependent variable: } \\
\text { Spread (in percentage terms) }\end{array}$} & \multicolumn{3}{|c|}{ Duration } \\
\hline & 12 months & $>12$ month & all \\
\hline \multirow[t]{2}{*}{ Constant (Other) } & $2.85 * * *$ & $5.31 * * *$ & $4.51 * * *$ \\
\hline & $(-51.02)$ & $(-123.82)$ & $(-39.58)$ \\
\hline \multirow[t]{2}{*}{ Duration (month) } & & $-0.02 * * *$ & $0.03 * * *$ \\
\hline & & $(-14.37)$ & $(-41.01)$ \\
\hline \multirow[t]{2}{*}{ Duration^2 } & & $0.00 * * *$ & $-0.00 * * *$ \\
\hline & & $(-18.83)$ & $(-20.86)$ \\
\hline \multirow[t]{2}{*}{ Amount $(10,000 €)$} & $-0.02 * * *$ & $-0.02 * * *$ & $-0.02 * * *$ \\
\hline & $(-17.56)$ & $(-43.78)$ & $(-45.76)$ \\
\hline \multirow[t]{2}{*}{ Renovation } & $0.08 * * *$ & $-0.03 *$ & $0.02 *$ \\
\hline & $(-3.83)$ & $(-2.29)$ & $(-2.07)$ \\
\hline \multirow[t]{2}{*}{ Renovation green } & $0.31 * * *$ & $-0.06 * * *$ & $0.04 * * *$ \\
\hline & $(-13.2)$ & $(-5.60)$ & $(-3.76)$ \\
\hline \multirow[t]{2}{*}{ Vehicle } & $0.08^{* *}$ & $-0.05 * * *$ & $-0.03 *$ \\
\hline & $(-3.12)$ & $(-4.32)$ & $(-2.55)$ \\
\hline \multirow[t]{2}{*}{ Vehicle green } & $0.05^{* *}$ & $-0.56 * * *$ & $-0.50 * * *$ \\
\hline & $(-1.84)$ & $(-37.02)$ & $(-33.56)$ \\
\hline Institution dummy & YES & YES & YES \\
\hline Institution dummy*Time dummy & YES & YES & YES \\
\hline $\mathrm{N}$ & 34,135 & 206,827 & 240,962 \\
\hline R-sq & 0.662 & 0.469 & 0.415 \\
\hline adj. R-sq & 0.652 & 0.466 & 0.413 \\
\hline
\end{tabular}

\subsection{Effects by lending institution}

We run an alternative specification of model 3 with an additional interaction term $D_{c} I_{k}$ meant to capture the idiosyncratic way in which institutions price the risk associated with loan designations, as compared to the market. The results are displayed in Table 7. Generally speaking, Cofidis, Credit Mutuel, Société Générale et Cofinoga post the highest interest rates while LCL, BNP, Caisse d'Epargne and Cetelem post the lowest rates (column 1). The specific way in which an institution values a project category is given by the sum of the institution coefficient in the first column, the project category coefficient in the first row and the appropriate coefficient in the institution-category matrix. Thus estimated, the institutions' pricing strategies appear highly heterogeneous. In particular, among the institutions making a distinction between green and conventional renovations, Domofinance, Financo and Prêt d'union offer lower interest rates for the former, while Cetelem adopts the opposite strategy. 
Table 7: Effects by loan type and lenders

\begin{tabular}{|c|c|c|c|c|c|}
\hline & \multirow[b]{2}{*}{ Institution FE } & \\
\hline & & Renovation & $\begin{array}{c}\text { Renovation } \\
\text { Green }\end{array}$ & Vehicle & $\begin{array}{c}\text { Vehicle } \\
\text { Green }\end{array}$ \\
\hline & & $-0.32 * * *$ & -0.00 & $-0.41 * * *$ & $-0.77 * * *$ \\
\hline & & \multicolumn{4}{|c|}{ Supplementary Loan*Institution FE } \\
\hline BNP & $-0.81 * * *$ & $0.33^{* * *}$ & & $-0.21 * *$ & \\
\hline CAISSE D'EPARGNE & $-1.09 * * *$ & $1.66 * * *$ & & $2.13^{* * *}$ & \\
\hline CETELEM & $-0.98 * * *$ & $0.58 * * *$ & $0.44 * * *$ & 0.08 & \\
\hline COFIDIS & $2.07 * * *$ & $0.24 * *$ & & $0.44 * * *$ & \\
\hline COFINOGA & $0.45^{* *}$ & $-0.30 * *$ & & -0.14 & \\
\hline CREDIT AGRICOLE & -0.06 & $0.39 * * *$ & & $0.21^{*}$ & \\
\hline CREDIT MUTUEL & $0.82 * * *$ & $-3.28 * * *$ & & $-0.52 * * *$ & \\
\hline DOMOFINANCE & $-0.46 * * *$ & $-0.34 * * *$ & $-0.59 * * *$ & & \\
\hline FINANCO & -0.05 & -0.09 & $-0.55 * * *$ & $-0.37 * * *$ & \\
\hline FRANFINANCE & $-0.87 * * *$ & $0.46 * * *$ & & & \\
\hline LCL & $-2.81 * * *$ & & & $1.30 * * *$ & \\
\hline PRET D'UNION & $-0.35 * *$ & & & $0.41 * * *$ & \\
\hline SOCIETE GENERALE & $0.52 * *$ & & & & \\
\hline SOFINCO & $-0.51 * *$ & $1.48 * * *$ & & & \\
\hline
\end{tabular}

We then analyze whether being awarded a green certification affects the pricing behavior of lenders. Three certifications exist in France: $\operatorname{TEEC}^{10}$ (Transition énergétique et écologique pour le climat) awarded by the Ministry of Finance since 10th December 2015; ISR $^{11}$ (Investissement socialement responsable) awarded by the Ministry of Finance since September 2015, and the PRI ${ }^{12}$ (Principles for Responsible Investment) launched in April 2006 by the United Nations for corporations worldwide. While the TEEC and ISR are awarded after an extensive external audit, the PRI consists of a list of recommendations that a signatory commits to follow. In general, these certifications do not involve ex post verification. We assume that lenders apply their guiding principles of the certifications to their consumption loans, at least for advertising purposes.

The table below displays the dates of certification award to at least one fund of a banking group. For our analysis, we consider a banking group to be green-certified if it was awarded at least one certification by the beginning of 2015 .

\begin{tabular}{|c|c|c|c|c|}
\hline & \multicolumn{3}{|c|}{ Date of certification award } & \multirow{2}{*}{$\begin{array}{l}\text { At least one certification by } \\
\text { the beginning of } 2015\end{array}$} \\
\hline & PRI & TEEC & ISR & \\
\hline BNP & $27 / 04 / 2006$ & & 01/09/2015 & YES \\
\hline
\end{tabular}

\footnotetext{
${ }^{10}$ https://www.ecologique-solidaire.gouv.fr/label-transition-energetique-et-ecologique-climat

${ }^{11}$ https://www.lelabelisr.fr/quest-ce-que-isr/

12 https://www.unpri.org/
} 


$\begin{array}{lcccc}\text { BPCE } & & & \text { NO } \\ \text { Credit Agricole } & 08 / 03 / 2010 & & & \text { YES } \\ \text { Credit Mutuel } & 14 / 09 / 2012 & 01 / 06 / 2017 & \text { after 01/09/2016 } & \text { YES } \\ \text { LBP } & 20 / 01 / 2009 & 06 / 06 / 2017 & 13 / 09 / 2017 & \text { YES } \\ \text { Societe generale } & & & & \text { NO }\end{array}$

We run the baseline regression with five loan categories on the sample of green-certified lenders and non-certified ones. The results are presented in Table below.

\begin{tabular}{|c|c|c|}
\hline \multirow{2}{*}{$\begin{array}{l}\text { Dependent variable } \\
\text { spread }\end{array}$} & \multicolumn{2}{|c|}{ Green label } \\
\hline & No & Yes \\
\hline \multirow[t]{2}{*}{ Constant } & $4.11^{* * *}$ & $4.28^{* * *}$ \\
\hline & $(43.46)$ & (79.21) \\
\hline \multirow[t]{2}{*}{ Duration (months) } & $0.04 * * *$ & $0.035^{* * *}$ \\
\hline & $(19.28)$ & $(36.83)$ \\
\hline \multirow[t]{2}{*}{ Duration ${ }^{2}$ (months) } & $-0.00 * * *$ & $-0.00 * * *$ \\
\hline & $(-11.06)$ & $(-20.76)$ \\
\hline \multirow[t]{2}{*}{ Amount $(10,000 €)$} & $-0.05^{* * *}$ & $-0.02 * * *$ \\
\hline & $(-24.28)$ & $(-30.14)$ \\
\hline \multirow[t]{2}{*}{ Dummy Retrofit } & $1.08^{* * *}$ & $-0.20 * * *$ \\
\hline & $(33.88)$ & $(-15.06)$ \\
\hline \multirow[t]{2}{*}{ Dummy Retrofit Green } & & $-0.82 * * *$ \\
\hline & & $(-68.65)$ \\
\hline \multirow[t]{2}{*}{ Dummy Vehicle } & $1.31^{* * *}$ & $-0.31 * * *$ \\
\hline & $(41.17)$ & $(-25.54)$ \\
\hline \multirow[t]{2}{*}{ Dummy Vehicle Green } & & $-1.65^{* * *}$ \\
\hline & & $(-95.33)$ \\
\hline Time fixed effects & YES & YES \\
\hline $\mathrm{N}$ & 22213 & 218749 \\
\hline R-sq & 0.212 & 0.138 \\
\hline $\operatorname{adj.~R-sq~}$ & 0.209 & 0.138 \\
\hline
\end{tabular}

$\mathrm{t}$ statistics in parentheses

${ }^{*} p<0.05,{ }^{* *} p<0.01,{ }^{* * *} p<0.001$ 
Not surprisingly, green loan options are only offered by green-certified lenders (BNP Paribas, Cetelem, Domofinance, Financo and Prêt d'union belonging to the green-certified groups BNP Paribas and Crédit Mutuel). The regression confirms that they are responsible for the green discount found previously in the full sample: indeed, green-certified lenders tend to assign lower rates to green projects, for renovations and even more so for vehicles. The regressions nevertheless suggest that the two groups adopt opposite pricing strategies with respect to Hypothesis 2. The screening effect is observed regardless of the certification of the lender. However, non-certified lenders set lower rates to renovation projects, while green-certified lenders do the opposite, even more so for green projects. 


\section{Robustness checks}

\subsection{Macroeconomic and financial controls}

We substitute a set of macroeconomic and financial variables for time fixed effects and examine how it affects the values of the estimated coefficients of loan categories. We estimate the following model:

$$
s_{\text {kamct }}=\alpha_{0}+\alpha_{1} L_{a m}+\alpha_{2} I_{k}+\alpha_{3}^{M} M_{t}+\alpha_{3}^{F} F_{t}+\beta_{c} D_{c}+\varepsilon_{\text {kamct }},
$$

where $M_{t}$ is a vector of macroeconomic variables, $F_{t}$ a vector of financial variables, and all other variables are those defined in the previous model. Macroeconomic controls include: the inflation rate, as measured by the harmonized index of consumer prices; the unemployment rate, which approximates the phase of the business cycle; the interest rate on one-year government bonds in the Euro area, which captures the quantitative easing in which the European Central Bank (ECB) engaged during the period. Financial controls include: the spread between the return on the CAC40 index and the interest rate on one-year government bonds, which approximates the volatility of the stock market; the stress index provided by the ECB, which approximates the volatility in the bond market; ${ }^{13}$ and investors' expectations, as measured by the slope of the yield difference between ten-year and one-year government bonds.

These substitutions do not qualitatively affect the results of the baseline model and preserve the ranking between the interest rates associated with different project categories (Table 9). Macroeconomic and financial factors explain a very modest part of the variation of the spread, which is consistent with previous findings (Gambacorta, 2008). Unemployment stands out at the only added control with a statistically significant effect. Its negative sign could be explained by a depressed demand, to which lenders respond with lower interest rates. Another explanation could be that unemployment insurance offered by lenders during the negotiation process can mitigate risks (Hsu et al., 2012). Despite being non-significant, estimates for the other variables have the expected polarity. Quantitative easing has a positive effect, suggesting that institutions benefited from a loosening of the monetary policy, possibly at the expense of consumers. Inflation too has a positive effect, suggesting that cost pass-through is affected by some market power. Higher risks in the equity market, as approximated by the two volatility indices, increase the spread, suggesting that lenders transfer part of the portfolio risks to their clients. The impact of the yield curve slope is positive, suggesting that optimistic expectations are associated with a higher demand for consumer loans.

\footnotetext{
${ }^{13}$ Euro area (changing composition), Stress subindice - Bond Market - realised volatility of the German 10-year benchmark government bond index, yield spread between A-rated non-financial corporations and government bonds (7-year maturity bracket), and 10-year interest rate swap spread, Contribution.
} 
Table 9: Effect of macroeconomic and financial controls

\begin{tabular}{|c|c|c|c|c|}
\hline \multirow{2}{*}{$\begin{array}{l}\text { Dependent variable } \\
\text { APY spread (in percentage points) }\end{array}$} & \multicolumn{4}{|c|}{ Baseline model with controls for } \\
\hline & $\begin{array}{c}\text { Baseline } \\
\text { model }\end{array}$ & $\begin{array}{l}\text { Macro } \\
\text { factors }\end{array}$ & $\begin{array}{c}\text { Financial } \\
\text { factors }\end{array}$ & $\begin{array}{l}\text { Macro and } \\
\text { financial } \\
\text { factors }\end{array}$ \\
\hline \multirow[t]{2}{*}{ Constant (Other) } & $4.51 * * *$ & $6.79 * * *$ & -5.22 & -5.13 \\
\hline & $(-39.58)$ & $(-6.94)$ & $(-0.00)$ & $(-0.00)$ \\
\hline \multirow[t]{2}{*}{ Duration (month) } & $0.03 * * *$ & $0.03 * * *$ & $0.03 * * *$ & $0.03 * * *$ \\
\hline & $(-41.01)$ & $(-41.02)$ & $(-41.01)$ & $(-41.02)$ \\
\hline \multirow[t]{2}{*}{ Duration^2 } & $-0.00 * * *$ & $-0.00 * * *$ & $-0.00 * * *$ & $-0.00 * * *$ \\
\hline & $(-20.86)$ & $(-20.86)$ & $(-20.86)$ & $(-20.86)$ \\
\hline \multirow[t]{2}{*}{ Amount $(10,000 €)$} & $-0.02 * * *$ & $-0.02 * * *$ & $-0.02 * * *$ & $-0.02 * * *$ \\
\hline & $(-45.76)$ & $(-45.75)$ & $(-45.76)$ & $(-45.75)$ \\
\hline \multirow[t]{2}{*}{ Dummy Retrofit } & $0.02 *$ & $0.02 *$ & $0.02 *$ & $0.02 *$ \\
\hline & $(-2.07)$ & $(-1.88)$ & $(-2.07)$ & $(-1.88)$ \\
\hline \multirow[t]{2}{*}{ Dummy Retrofit Green } & $0.04 * * *$ & $0.04 * * *$ & $0.04 * * *$ & $0.04 * * *$ \\
\hline & $(-3.76)$ & $(-3.63)$ & $(-3.76)$ & $(-3.63)$ \\
\hline \multirow[t]{2}{*}{ Dummy Vehicle } & $-0.03 *$ & $-0.03 * *$ & $-0.03 *$ & $-0.03 * *$ \\
\hline & $(-2.55)$ & $(-2.83)$ & $(-2.55)$ & $(-2.83)$ \\
\hline \multirow[t]{2}{*}{ Dummy Vehicle Green } & $-0.50 * * *$ & $-0.50 * * *$ & $-0.50 * * *$ & $-0.50 * * *$ \\
\hline & $(-33.56)$ & $(-33.78)$ & $(-33.56)$ & $(-33.78)$ \\
\hline \multirow[t]{2}{*}{ One-year bonds } & & 11.33 & & -1.27 \\
\hline & & $(0.34)$ & & $(-1.23)$ \\
\hline \multirow[t]{2}{*}{ Price index } & & 0.20 & & -0.03 \\
\hline & & $(0.97)$ & & $(-0.68)$ \\
\hline \multirow[t]{2}{*}{ Unemployment } & & $-0.11 * * *$ & & $-0.11 * * *$ \\
\hline & & $(-6.29)$ & & $(-6.29)$ \\
\hline \multirow[t]{2}{*}{ CAC40 } & & & 1.87 & 2.17 \\
\hline & & & $(-0.65)$ & $(0.65)$ \\
\hline \multirow[t]{2}{*}{ Stress index } & & & 15.84 & 17.02 \\
\hline & & & $(1.03)$ & $(-0.65)$ \\
\hline \multirow[t]{2}{*}{ Yield curve slope } & & & 0.69 & -0.07 \\
\hline & & & $(0.49)$ & $(-0.39)$ \\
\hline$N$ & 240,962 & 240,962 & 240,962 & 240,962 \\
\hline $\mathrm{R}-\mathrm{sq}$ & 0.415 & 0.416 & 0.415 & 0.416 \\
\hline adj. R-sq & 0.413 & 0.413 & 0.413 & 0.413 \\
\hline
\end{tabular}

$\mathrm{t}$ statistics in parentheses

${ }^{*} \mathrm{p}<0.05 .{ }^{* *} \mathrm{p}<0.01 .{ }^{* * *} \mathrm{p}<0.001$

\subsection{Placebo tests}

As stated in Section 3.2, we build our own categorization of the 90 distinct designations recorded by the robot. While most designations labels are clear enough to be categorized in a straightforward manner, green-renovation labels are subject to interpretation. We conduct two placebo tests to examine the relevance of our categorization in general, and that of the green-renovation category in particular. 
In the first placebo test, we randomly assign each of the 90 designations to one out of five arbitrary categories, following a uniform distribution. We then produce OLS estimates of model 3 with these categories, simply labelled 1 to 5 . We repeat this procedure 1,000 times. Figure 7 displays the distribution of estimated coefficients for all categories. Table 10 displays the mean of obtained coefficients and $p$ values. The table confirms that the coefficients estimated for arbitrary categories are centered around zero. The mean of the $p$-value is 0.5 and it is uniformly distributed, as it should be under the null hypothesis that the value of each of the coefficients is zero. The results lead us to the conclusion that our five-item categorization is meaningful.
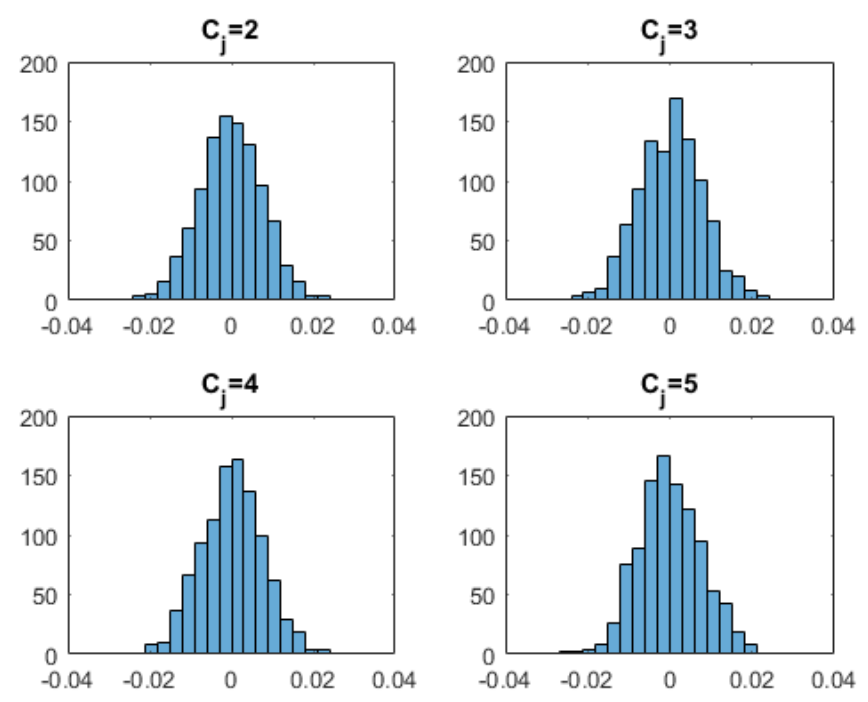

Figure 7: Placebo test on all categories

Table 10: Placebo test on all categories

\begin{tabular}{lcccc} 
& $\mathrm{Cj}=2$ & $\mathrm{Cj}=3$ & $\mathrm{Cj}=4$ & $\mathrm{Cj}=5$ \\
\hline Average $\beta 1$ & & & & \\
Average $\sigma_{\beta 1}$ & 0.00 & 0.00 & 0.00 & 0.00 \\
Average $p$-value & 0.01 & 0.01 & 0.01 & 0.01 \\
& 0.50 & 0.50 & 0.51 & 0.50 \\
\hline
\end{tabular}

In the second placebo test, we restrict the procedure to those designations which initially fell in either renovation or green renovation categories. We randomly assign those designations to two arbitrary categories while maintaining other designations in their initial category (vehicle, green vehicle and other). We then estimate model 3 and repeat the procedure 1,000 times. The distributions of estimated coefficients appear much narrower for the two vehicle categories than for the two arbitrary renovation categories (Figure 8). The latter are moreover centered around the same value. The mean $p$-value of 0 
indicates that, on average, the null hypothesis on the insignificance of the coefficients is rejected (Table 11). Moreover, the probability distribution of the $p$-value is not uniform but has a bell shape skewed towards zero, as it should when the null is rejected. This indicates that, irrespective of the green attribute, the retrofit category has a significant impact on the spread. A statistical test fails to reject the null hypothesis that estimated coefficients for the two arbitrary categories are equal $(F(1,239939)=0.16$; Prob $>\mathrm{F}=0.6901$ ), as the two placebo categories are now indistinguishable. However, they are different from our baseline estimates obtained with our categorization $(F(1,239939)=9.03$; Prob $>F=0.0001)$, thus implying that our categorization of conventional and green renovations is also meaningful.
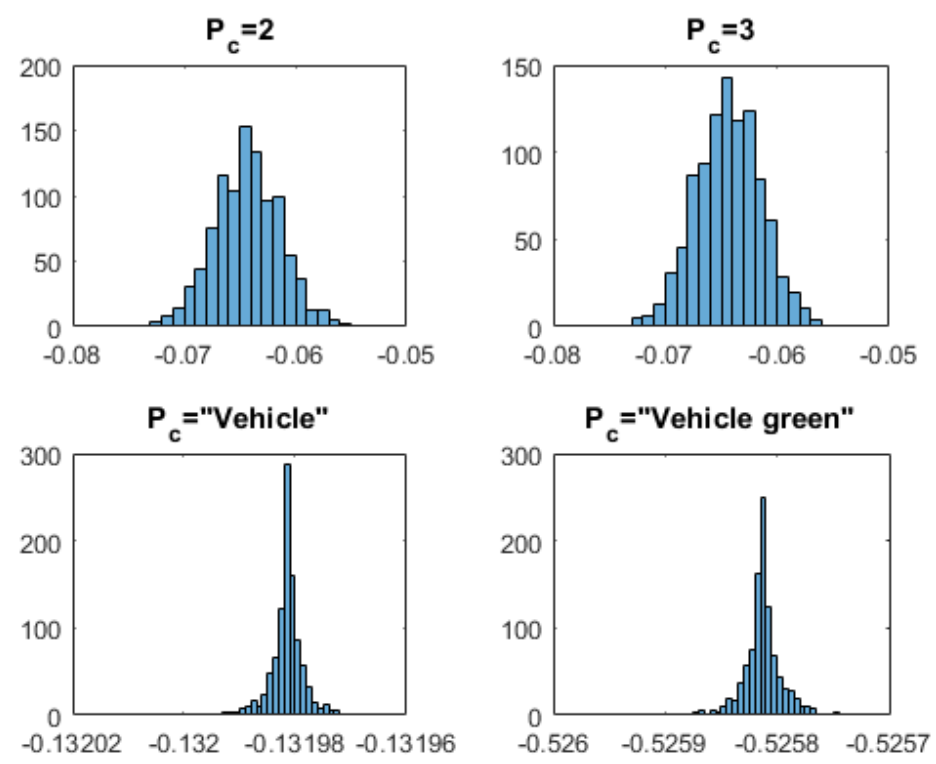

Figure 8: Placebo test on renovation categories

Table 11: Placebo test on renovation categories

\begin{tabular}{lcccc} 
& Renovation 1 & Renovation 2 & Vehicle & Vehicle green \\
\hline & & & & \\
Average $\beta 1$ & 0.03 & 0.03 & -0.03 & -0.51 \\
Average $\sigma_{\beta 1}$ & 0.01 & 0.01 & 0.01 & 0.02 \\
Average p-value & 0.00 & 0.00 & 0.00 & 0.00 \\
& & & & \\
\hline
\end{tabular}




\section{Conclusion}

The energy efficiency improvement of the residential buildings are key for reducing the carbon dioxide emission. Like most OECD countries, France is characterized by stringent building codes in new constructions, yet a slow turnover of its building stock -about $1 \%$ per year. This makes the renovation of existing buildings crucial for reducing energy demand, and, ultimately, $\mathrm{CO}_{2}$ emissions, in the building sector. Back-of-the envelope calculations suggest that, with a government target of 500,000 annual renovations, at a unit cost of $€ 10,000$ on average, financed by personal consumption loan in $20-40 \%$ of cases, yearly borrowing needs for home energy renovation amount to $€ 1$ to $€ 2$ billion.

The purpose of this paper is to examine the pricing behavior of financial institutions in relation to home energy renovation. For this purpose, we have assembled a unique panel dataset of simulated-loan data to investigate how the interest rate for green projects compares to that of conventional projects on the one hand, how the interest rate for renovations compares to that of vehicles on the other. The dataset contains weekly data on posted interest rate covering the period 2015-2016 for 15 financial institutions.

We test two hypotheses. The first hypothesis examines whether the loans labelled as "green" (whether for a green vehicle or a green renovation) are charged lower interest rate with respect to the conventional loans. This hypothesis allows us to test the pure effect of the green status of a loan. The second hypothesis checks if renovation loans are charged higher interest rates than other loan types. This hypothesis allows us to examine potential screening issues based on the project type (from which lenders might infer borrower characteristics). We find that, on average for the whole sample, the first hypothesis is verified for the vehicles but rejected for renovations, implying that a green label does not reduce the price of a renovation loan. The second hypothesis on average is rejected. Taken together, these results imply that energy renovation projects are subject to two effects pushing their interest rate price upwards: the green label and the screening effect.

Our data undergo important changes in the beginning of 2016, with the rates for green projects shifting significantly downside and a more pronounced downward slope for some credit types (which is plausibly related to Quantitative Easing of the European Central Bank). We therefore test the two hypotheses on yearly subsamples for 2015 and 2016. Regarding the first hypothesis, we found a green discount in 2016, but not in 2015. This result is consistent with the notion that financial agents increasingly value environmental aspects, as recently substantiated by An and Pivo (2018) in the US market for commercial mortgages and Karpf and Mandel (2018) in the US market for municipal bonds. Regarding the second hypothesis, the differences we observe in the interest rates offered for different types of loans is consistent with lenders using loan designation as a screening device for price discrimination of their borrowers. Specifically, our findings suggest dominance of the risk channel in 2015 and dominance of the WTP channel in 2016 in lenders' pricing strategies. Generally speaking, our results are small in magnitude but statistically significant and robust to a variety of specifications. They together suggest that different types of information asymmetries might affect the market for unsecured credit in France, at different points in time. This is particularly true for home energy retrofits, which can be interpreted as a new form of energy efficiency gap. 
Furthermore, we find that the effects differ for short-term loans and long-term loans. Specifically, we find that neutrality of the green label only applies to short-term loans (up to 12 months). However, we observe the screening effect irrespective of the loan duration.

We also examine whether being awarded a green certification (PRI, TEEC or ISR) impacts institutions' pricing behavior. We first observe that green-certified banking groups are those that make a distinction between green and conventional loans and thus are the only ones responsible for the green discount or premium. We further find that, unlike their non-certified counterparts, green-certified lenders price renovation projects at higher rates than vehicles.

\section{Acknowledgements}

We gratefully acknowledge funding from the European Investment Bank Institute under the University Research Sponsorship Programme, Grant EIBI/KnP/TT/ck (1-RGI-C311). We thank Dominique Berthon for excellent research assistance that set the stage for the project. We thank Leonardo Gambacorta, Sven Heim, Sébastien Houde, Elisabetta lossa, Claire Labonne, Antoine Lallour, Maria Loumioti, Antoine Mandel, Tien Viet Nguyen, Julia Schmidt, Mattia Girotti and seminar participants at ETH Zürich and CERNA Mines ParisTech for useful comments on earlier drafts. 


\section{References}

ACPR, 2016. Annual report.

ADEME, 2018. Enquête TREMI. Travaux de Rénovation Energétique des Maisons Individuelles, campagne 2017. https://www.ademe.fr/sites/default/files/assets/documents/enquete-tremi-2017-010422.pdf.

Allcott, H., Greenstone, M., 2012. Is There an Energy Efficiency Gap? Journal of Economic Perspectives 26, 328. https://doi.org/10.1257/jep.26.1.3.

Allen, J. , Clark, R. and Houde, J. (2014a), Price Dispersion in Mortgage Markets. J Ind Econ, 62: 377-416. doi:10.1111/joie.12046.

Allen, J. , Clark, R. and Houde, J. (2014b), The Effect of Mergers in Search Markets: Evidence from the Canadian Mortgage Industry. American Economic Review, 104 (10): 3365-96.

An, X., Pivo, G., 2018. Green Buildings in Commercial Mortgage Backed Securities: The Effects of LEED and Energy Star Certification on Default Risk and Loan Terms. Real Estate Economics. https://doi.org/10.1111/1540-6229.12228.

Angrist, Joshua David, and Jörn-Steffen Pischke. 2009. Mostly harmless econometrics: an empiricist's companion. Princeton: Princeton University Press.

Athreya, Kartik, Xuan S. Tam, and Eric R. Young. 2012. "A Quantitative Theory of Information and Unsecured Credit." American Economic Journal: Macroeconomics, 4 (3): 153-83.

Brounen, D., Kok, N., 2011. On the economics of energy labels in the housing market. Journal of Environmental Economics and Management 62, 166-179. https://doi.org/10.1016/i.jeem.2010.11.006.

Cavallo, A., Rigobon, R., 2016. The Billion Prices Project: Using Online Prices for Measurement and Research. Journal of Economic Perspectives 30, 151-17, . https://doi.org/10.1257/jep.30.2.151.

Crawford, Gregory S., and Nicola Pavanini, and Fabiano Schivardi, 2018. "Asymmetric Information and Imperfect Competition in Lending Markets," American Economic Review, American Economic Association, vol. 108(7), pages 1659-1701, July.

Duca, J.V., Rosenthal, S.S., 1993. Borrowing Constraints, Household Debt, and Racial Discrimination in Loan Markets. Journal of Financial Intermediation 3, 77-103. https://doi.org/10.1006/jfin.1993.1003

Europe Economics.

Einav, L., Jenkins, M. and Levin, J., 2012. Contract Pricing in Consumer Credit Markets. Econometrica, 80: 1387-1432. doi:10.3982/ECTA7677.

Fowlie, M., Greenstone, M., Wolfram, C., 2018. Do Energy Efficiency Investments Deliver? Evidence from the Weatherization Assistance Program. Quarterly Journal of Economics.

Gambacorta, L., 2008. How do banks set interest rates? European Economic Review 52, 792-819. https://doi.org/10.1016/i.euroecorev.2007.06.022. 
Gerarden, T.D., Newell, R.G., Stavins, R.N., 2017. Assessing the Energy-Efficiency Gap. Journal of Economic Literature 55, 1486-1525. https://doi.org/10.1257/jel.20161360.

Gillingham, K., Newell, R.G., Palmer, K., 2009. Energy Efficiency Economics and Policy. Annual Review of Resource Economics 1, 597-620. https://doi.org/10.1146/annurev.resource.102308.124234.

Giraudet, L.-G., 2018. Energy efficiency as a credence good : A review of informational barriers to building energy savings. FAERE Working Paper 2018.07. http://faere.fr/pub/WorkingPapers/Giraudet FAERE WP2018.07.pdf.

Giraudet, L.-G., Houde, S., Maher, J., 2018a. Moral hazard and the energy efficiency gap: Theory and evidence. Journal of the Association of Environmental and Resource Economists forthcoming.

Giraudet, L.-G., Bourgeois, C., Quirion, P., 2018b. Long-term efficiency and distributional impacts of energy saving policies in the French residential sector. https://hal.archives-ouvertes.fr/hal-01890642.

Graff Zivin, J., Novan, K., 2016. Upgrading Efficiency and Behavior: Electricity Savings from Residential Weatherization Programs. The Energy Journal 37. https://doi.org/10.5547/01956574.37.4.jziv

Gross, David B., and Nicholas S. Souleles, 2002. "Do Liquidity Constraints and Interest Rates Matter for Consumer Behavior? Evidence from Credit Card Data." The Quarterly Journal of Economics 117 (1): 14985.

D'Haultfœuille, X., Givord, P., Boutin, X., 2014. The Environmental Effect of Green Taxation: The Case of the French Bonus/Malus. Econ J 124, F444-F480. https://doi.org/10.1111/ecoj.12089.

IEA, 2018. Energy Efficiency 2018: Analysis and outlooks to 2040. Market report series. https://webstore.iea.org/market-report-series-energy-efficiency-2018.

IGF and CGEDD, 2017. Aides à la rénovation énergétique des logements privés. http://cgedd.documentation.developpement-durable.gouv.fr/documents/cgedd/01086701 rapport.pdf.

IPCC, 2018. Global Warming of $1.5^{\circ} \mathrm{C}$. http://www.ipcc.ch/report/sr15.

Jaffe, A.B., Stavins, R.N., 1994. The energy-efficiency gap: What does it mean? Energy Policy 22, 804-810. https://doi.org/10.1016/0301-4215(94)90138-4.

Kaza, N., Quercia, R.G., Tian, C.Y., 2014. Home Energy Efficiency and Mortgage Risks. Cityscape: A Journal of Policy Development and Research 16, 279-298.

Meilleurtaux.com, 2015. "Crédit à la consommation : portrait de l'emprunteur type ». Communiqué de presse, 4 mai 2015. https://www.meilleurtaux.com/images/presse/20150504 Credit-conso profil-desemprunteurs.pda.

Metcalf, G.E., Hassett, K.A., 1999. Measuring the Energy Savings from Home Improvement Investments: Evidence from Monthly Billing Data. Review of Economics and Statistics 81, 516-528. https://doi.org/10.1162/003465399558274. 
Mouillard, M., 2018. Tableau de bord 2017. L'observatoire du crédit aux ménages, 30ème rapport annuel.

Nelson, C.R., A.F. Siegel, 1987. Parsimonious Modeling of Yield Curves. Journal of Business, 60(4):473-489.

Palmer, K., Walls, M., Gerarden, T., 2012. Borrowing to Save Energy: An Assessment of Energy-Efficiency Financing Programs, Resources for the future.

Peterson, R.L., 1981. An Investigation of Sex Discrimination in Commercial Banks' Direct Consumer Lending. The Bell Journal of Economics 12, 547-561. https://doi.org/10.2307/3003571.

Ponce, Alejandro, Enrique Seira, and Guillermo Zamarripa. 2014."Borrowing on the Wrong Credit Card: Evidence from Mexico."

Sánchez, J. M. (2018), THE INFORMATION TECHNOLOGY REVOLUTION AND THE UNSECURED CREDIT MARKET. Econ Inq, 56: 914-930. doi:10.1111/ecin.12519.

Scott Morton, F., Zettelmeyer, F., and Silva-Risso, J. , 2003. 'Consumer Information and Discrimination: Does the Internet Affect the Pricing of New Cars to Women and Minorities?' Quantitative Marketing and Economics,1, pp. 65-92.

SOFINCO, 2010. Le financement automobile: pas de vente sans crédit! Panorama du crédit à la consommation de SOFINCO.

Zinman, J. (2014). Consumer Credit: Too Much or Too Little (or Just Right)? The Journal of Legal Studies, 43(S2), S209-S237. doi:10.1086/676133 